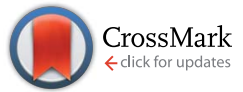

Cite this: Chem. Sci., 2014, 5, 4017

\title{
Oxygen chemisorption/desorption in a reversible single-crystal-to-single-crystal transformation $\uparrow$
}

\author{
Jonas Sundberg, ${ }^{\mathrm{a}}$ Lisa J. Cameron, ${ }^{\mathrm{b}}$ Peter D. Southon, ${ }^{\mathrm{b}}$ Cameron J. Kepert ${ }^{\mathrm{b}}$ \\ and Christine J. McKenzie*a
}

Crystalline salts of a series of cationic multimetallic cobalt complexes reversibly, selectively and stoichiometrically chemisorb dioxygen in a process involving the two electron oxidation of dimetallic sites with concurrent reduction of two equivalents of sorbed $\mathrm{O}_{2}$ to form $\mu-\eta^{1}, \eta^{2}$-peroxide ligands. The coordinating ability of counteranions, $\mathrm{ClO}_{4}{ }^{-}, \mathrm{PF}_{6}{ }^{-}, \mathrm{BF}_{4}{ }^{-}, \mathrm{CF}_{3} \mathrm{SO}_{3}{ }^{-}$and $\mathrm{NO}_{3}{ }^{-}$determine the $\mathrm{O}_{2}$ affinity of the deoxygenated forms, and the nitrate and triflate salts sorb dioxygen at a significantly slower rate compared to the $\mathrm{PF}_{6}{ }^{-}$and $\mathrm{BF}_{4}{ }^{-}$salts (hours versus sub-seconds at ambient temperature and pressure). Single crystal $\mathrm{X}$-ray structural determination for a nitrate salt of the 2-aminoterephthalato-linked deoxy system, $\left[\left\{(\mathrm{bpbp}) \mathrm{CO}_{2}{ }^{\prime \prime}\left(\mathrm{NO}_{3}\right)\right\}_{2}\left(\mathrm{NH}_{2} \mathrm{bdc}\right)\right]\left(\mathrm{NO}_{3}\right)_{2} \cdot 2 \mathrm{H}_{2} \mathrm{O} \quad\left(\mathrm{bpbp}^{-}=2,6\right.$-bis $(\mathrm{N}, \mathrm{N}$-bis(2-pyridylmethyl)aminomethyl)-4-tert-butylphenolato, $\mathrm{NH}_{2} \mathrm{bdc}^{2-}=2$-amino-1,4-benzenedicarboxylato) shows that nitrate ions are coordinated as bridging ligands. These crystals undergo reversible single-crystal-tosingle-crystal (SC-to-SC) transformations on the stoichiometric uptake of $\mathrm{O}_{2}$. During this process $\mathrm{O}_{2}$ replaces the two nitrate ligands. Thus the Co ions are six coordinated in both the oxy and deoxy states. This SC-to-SC process involves the concerted fast migration of neutral dioxygen through the crystal lattice and the translational movement by $4-6 \AA$ of at least two of nitrate anions. Rapid hydration/ dehydration processes involving several molecules of co-crystallized water per unit cell accompany the reaction. Besides large atom movements involving $\mathrm{O}_{2}, \mathrm{NO}_{3}{ }^{-}$and $\mathrm{H}_{2} \mathrm{O}$, these impressive examples of consecutive SC-to-SC-to-SC transformations involve the cleavage of four bonds, and the creation of four new bonds, in one single molecule. The solid state structural rearrangements observed provide an explanation for the slower rates of dioxygen uptake for the complexes isolated as nitrate salts, and by inference, the triflate salts, compared to the salts of more weakly coordinating counteranions, $\mathrm{ClO}_{4}{ }^{-}$, $\mathrm{PF}_{6}{ }^{-}$and $\mathrm{BF}_{4}{ }^{-}$

Received 3rd June 2014

Accepted 11th July 2014

DOI: $10.1039 / c 4 s c 01636 j$

www.rsc.org/chemicalscience

\section{Introduction}

Reactions of dioxygen are essential in a wide range of biological and chemical processes: the reversible binding of dioxygen, its activation in order to prime it for the oxidation of substrates, and its release after formation. The presence of paramagnetic states of iron, copper, nickel and manganese in enzymes like hemoglobin, hemerythrin, hemocyanin, cytochrome P450s, superoxide dismustases and the Oxygen Evolving Center in photosynthesis is essential. The risk of formation of reactive oxygen species, and possible consequent non-specific chain reactions, mean that the metal-based redox reactions must be

${ }^{a}$ Department of Physics, Chemistry and Pharmacy, University of Southern Denmark, Campusvej 55, 5230 Odense M, Denmark. E-mail: mckenzie@sdu.dk; Fax: +456615 8760; Tel: +4565502518

${ }^{b}$ School of Chemistry, The University of Sydney, NSW 2006, Australia

$\dagger$ Electronic supplementary information (ESI) available: Supporting figures, Table of selected bond distances and angles. IR spectra. CCDC 1006439 and 1006440. For ESI and crystallographic data in CIF or other electronic format see DOI: 10.1039/c4sc01636j very finely adjusted to prevent one electron transfers and possible release of cytotoxic superoxide. $\mathrm{O}_{2}$ binding by metalloenzymes can be regarded as a highly selective "chemisorptive process", i.e., bond formation occurs between the $\mathrm{O}_{2}$ and the metal co-factors. The separation of $\mathrm{O}_{2}$ from other gases by reversible sorption is similarly essential for many industrial processes. However, efficiency and selectivity equal to biological processes has not yet been achieved. While $\mathrm{O}_{2}$ concentration by sorptive materials is potentially less energy intensive compared with cryogenic distillation, currently this method can be used only in applications where it is not required in higher purity. These processes, based on zeolite materials, ${ }^{1}$ are physisorptive in contrast to the aforementioned biological reactions. ${ }^{2}$ Solid state metal-organic compounds offer a chemical middle ground between dynamic and flexible enzymes and rigid inorganic zeolites for the design of materials capable of performing reversible $\mathrm{O}_{2}$ binding. An obvious place to start in the design of these materials is by exploiting coordination complexes which are known to perform this task in the solution state. Co and Ir complexes, e.g. $\mathrm{Co}(\text { salen })^{3}$ and Vaska's ${ }^{4}$ complex, have been long 
recognised as capable of oxidative addition and reductive elimination of $\mathrm{O}_{2}$ in solution as they cycle between $\mathrm{M}(\mathrm{I})$ and M(III) oxidation states. ${ }^{5}$ Thus it is not surprising that the immobilisation of these types of complexes in membranes ${ }^{6}$ and polymers, ${ }^{7}$ with the intention that practical materials and devices for $\mathrm{O}_{2}$ separation processes might be constructed, has been pursued. However, none of these systems has achieved the $\mathrm{O}_{2}$ binding active site concentration, nor the reversibility of $\left[\left\{(\mathrm{bpbp}) \mathrm{Co}_{2}{ }^{\mathrm{III}}\left(\mathrm{O}_{2}\right)\right\}_{2}(\mathrm{bdc})\right]\left(\mathrm{PF}_{6}\right)_{4}\left(\mathrm{bpbp}^{-}=2,6\right.$-bis $(N, N$-bis(2-pyridylmethyl)aminomethyl)-4-tert-butylphenolato, bdc ${ }^{2-}=1,4$ benzenedicarboxylato). The cation in this compound is shown in Scheme 1, structure 2a. The deoxy form, $2 \mathbf{a}_{\text {deoxy }}\left(\mathrm{PF}_{6}\right)_{4}$ reversibly binds $\mathrm{O}_{2}$ from air in the solid state with affinities equalling that of myoglobin. ${ }^{8}$ The $\mathrm{O}_{2}$ sorption/desorption process of this compound can be cycled many times without any loss of activity. Solid $2 \mathrm{a}\left(\mathrm{PF}_{6}\right)_{4} \cdot 3 \mathrm{H}_{2} \mathrm{O}$ concentrates $\mathrm{O}_{2}$ by a factor of 32 times the density of $\mathrm{O}_{2}$ gas at $1 \mathrm{~atm}$, or 160 times that in air. Apart from a higher capacity than the zeolites currently used on industrial scale for a far less efficient $\mathrm{O}_{2}$ concentration, what is very interesting is the extreme affinity that this material shows for $\mathrm{O}_{2}$. At room temperature an excess of the material will reversibly remove more than $99 \%$ of oxygen from the air with a 38 fold selectivity factor for $\mathrm{O}_{2}$ over $\mathrm{N}_{2}$. Compared to recently discovered systems showing selectivity for $\mathrm{O}_{2}$ uptake, this is almost double that of the dichromium(II)tetracarboxylate paddlewheel based metal-organic framework, ${ }^{9}$ and almost four times higher than the coordination network $\mathrm{Fe}_{2}$ (dobdc) (dobdc $^{4-}=2,5$-dioxido-1,4-benzenedicarboxylate) (MOF-74). ${ }^{10}$ Despite not being polymeric, $2 \mathrm{a}\left(\mathrm{PF}_{6}\right)_{4} \cdot 3 \mathrm{H}_{2} \mathrm{O}$ also shows greater stability towards irreversible redox processes. While the oxy $2 \mathrm{a}\left(\mathrm{PF}_{6}\right)_{4} \cdot 3 \mathrm{H}_{2} \mathrm{O}$ has been structurally characterized, the deoxy and by its nature, air sensitive form, $2 \mathbf{a}_{\text {deoxy }}\left(\mathrm{PF}_{6}\right)_{4}$, has not.

In solution, the $\mathrm{O}_{2}$ affinity of a series of parent dinuclear complexes, Scheme 1, structures 1a-e, is tuned by the substitutions on the basic framework using electron donating or withdrawing groups on the carboxylate co-ligand. ${ }^{11}$ Thus for every chloro group introduced onto the acetato bridge the $\mathrm{O}_{2}$ affinity is reduced. The $\mathrm{O}_{2}$ affinities for 1a-e ranged from similar to myoglobin through to haemoglobin respectively. Conversely, when a dicobalt complex was anchored to gold surfaces using 1f, the $\mathrm{O}_{2}$ affinity was increased so much that the system is no longer an effective reversible $\mathrm{O}_{2}$ binder. ${ }^{12}$ With a view to practical applications the motivation for the work described in this report was carried out to ascertain whether or not this considerable range of solution state tunability could be translated into the solid state. With readily tuneable solid state materials on hand it is possible to imagine the construction of systems, capable not only of $\mathrm{O}_{2}$ storage, but through layering, also of the vectorial transport of this biologically and industrially important molecule.

\section{Results and discussion}

\section{Synthesis}

The cationic oxy complexes depicted in Scheme 1 (1a-e and 2a) were previously isolated for the most part as perchlorate salts. The safety issues associated with the need for heating solid samples for the present study forced the preparation of alternative formulations. We have now synthesized 2a as two new salts along with relatives which are functionalized on the $\mathrm{bdc}^{2-}$ linker (2b-d) as hexafluorophosphate, tetrafluoroborate, triflate and nitrate salts. Typically the dinucleating pro-ligand, $\mathrm{bpbpH}$, the appropriate carboxylic acid and base were mixed in stoichiometric amounts in mixtures of methanol, acetone and $\mathrm{H}_{2} \mathrm{O}$ under aerobic conditions. This reaction results in dark solutions from which the near black Co(III) oxy forms (as depicted in Scheme 1) crystallize over hours to days. The production of crystalline materials was crucial for the observation of consistent sorption/desorption properties, suggesting that solid phase structure plays an important role in the chemisorptive properties of these materials. Rapid precipitation formed light brown amorphous powders, which were inactive or only minimally active towards reversible $\mathrm{O}_{2}$ binding. Apart from an apparent need for crystalline materials, and therewith highly regular 3D structures, a possible explanation for the colour and low $\mathrm{O}_{2}$ uptake is contamination by "met" $\left(\mathrm{Co}(\mathrm{II})_{2}\right.$ to $\mathrm{Co}(\mathrm{III})_{2}$-based oxidation only-no $\mathrm{O}_{2}$ binding and reduction) forms in which the carboxylato ligands are replaced by hydroxido. ${ }^{13}$ On heating, the crystalline materials change to a pink colour due to the loss of $\mathrm{O}_{2}$ and the generation of "deoxy" materials containing the

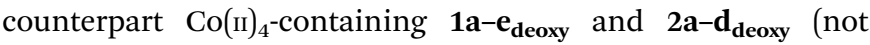
shown in Scheme 1). On cooling back to room temperature the dark colour re-emerges as the materials chemisorb $\mathrm{O}_{2}$ from the air to form the $\mathrm{Co}(\mathrm{III})_{4}$ oxy materials $1 \mathbf{1 a}-\mathbf{e}$ and $\mathbf{2 a}-\mathbf{d}$. This process was mostly accompanied by loss of crystal integrity, apart from one case, vide infra.
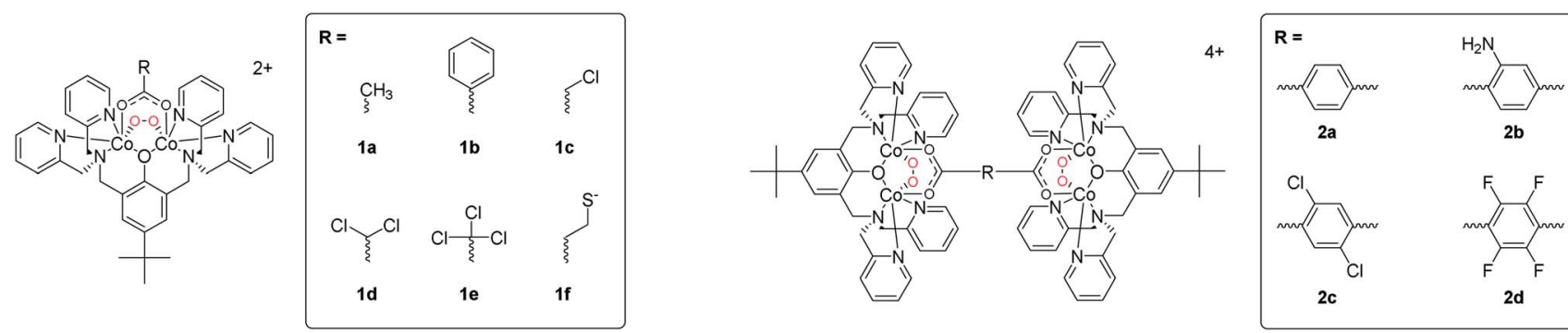

Scheme 1 Chemical structures of the cations in $\left[(\mathrm{bpbp}) \mathrm{Co}_{2}\left(\mathrm{O}_{2}\right)\left(\mathrm{O}_{2} \mathrm{CR}\right)\right](\mathrm{A})_{2}$ and $\left[\left\{(\mathrm{bpbp}) \mathrm{Co}_{2}\left(\mathrm{O}_{2}\right)\right\}_{2}\left(\mathrm{bdcR}_{4}\right)\right](\mathrm{A})_{4}$. Counteranions $(\mathrm{A}): \mathrm{ClO}_{4}{ }^{-}$, $\mathrm{PF}{ }_{6}^{-}$, $\mathrm{BF}_{4}{ }^{-}, \mathrm{CF}_{3} \mathrm{SO}_{3}{ }^{-}, \mathrm{NO}_{3}{ }^{-}$. 


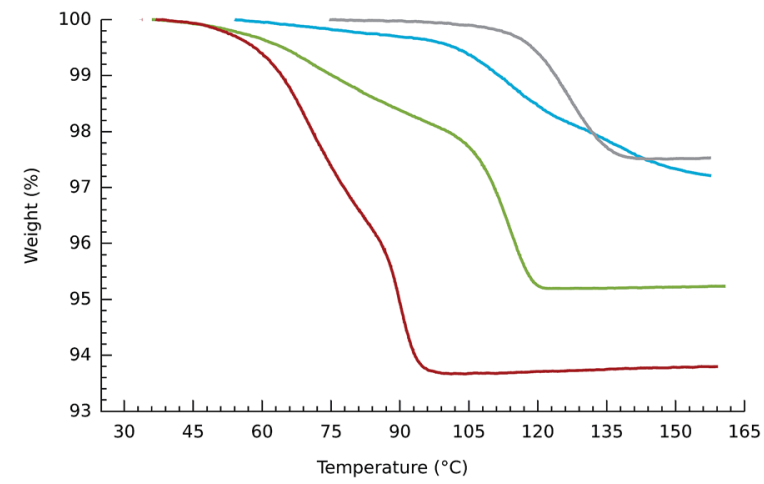

Fig. 1 Thermogravimetric plot for $\mathrm{NO}_{3}{ }^{-}$(red), $\mathrm{BF}_{4}{ }^{-}$(green), $\mathrm{PF}_{6}{ }^{-}$ (blue) and $\mathrm{CF}_{3} \mathrm{SO}_{3}{ }^{-}$(grey) salts of $\left[\left\{(\mathrm{bpbp}) \mathrm{CO}_{2}\left(\mathrm{O}_{2}\right)\right\}_{2}(\mathrm{bdc})\right]^{4+}(2 \mathrm{a})$ showing temperature dependent deoxygenation, accompanied by dehydration, see text.

\section{Thermogravimetry}

The tetracobalt series 2 , varied systematically with respect to counteranions and substitution on the benzene unit of the bdc $^{2-}$ co-ligand, show slight variation in the temperatures at which the samples of crystalline compounds release $\mathrm{O}_{2}$. Thermogravimetric plots of $\mathrm{O}_{2}$ release are shown in Fig. 1-3. Oxygen desorption for the parent $\left[\left\{(\mathrm{bpbp}) \mathrm{Co}_{2}{ }^{\mathrm{III}}\left(\mathrm{O}_{2}\right)\right\}_{2}(\mathrm{bdc})\right]^{4+}$, crystallized with four different counteranions, was measured by heating up to $160{ }^{\circ} \mathrm{C}$ at $5^{\circ} \mathrm{min}^{-1}$ under a steady flow of $\mathrm{N}_{2}$ gas. Elemental analyses indicate that the materials can contain significant and variable amounts of co-crystallized water and other solvent molecules as confirmed in the structurally characterised $\mathrm{ClO}_{4}{ }^{-},{ }^{14} \mathrm{PF}_{6}{ }^{-},{ }^{-8}$ and $\mathrm{NO}_{3}{ }^{-}$salts, vide infra. This complicates the interpretation of measurements, however, $\mathrm{O}_{2}$ desorption appears to be complete for all samples. As seen in Fig. 1 the samples of the triflate and the hexafluorophosphate salts used for the experiments do not appear to contain any cocrystallized solvent. A more obvious two-stage process of guest removal is evidenced by inflections in the TGA curves for the $\mathrm{BF}_{4}{ }^{-}$and $\mathrm{NO}_{3}{ }^{-}$salts, which may correspond to successive removal of water and oxygen with weight losses corresponding to two and four water molecules respectively. At approximately $100{ }^{\circ} \mathrm{C}$ the nitrate salt has lost both $\mathrm{O}_{2}$ molecules, whereas the

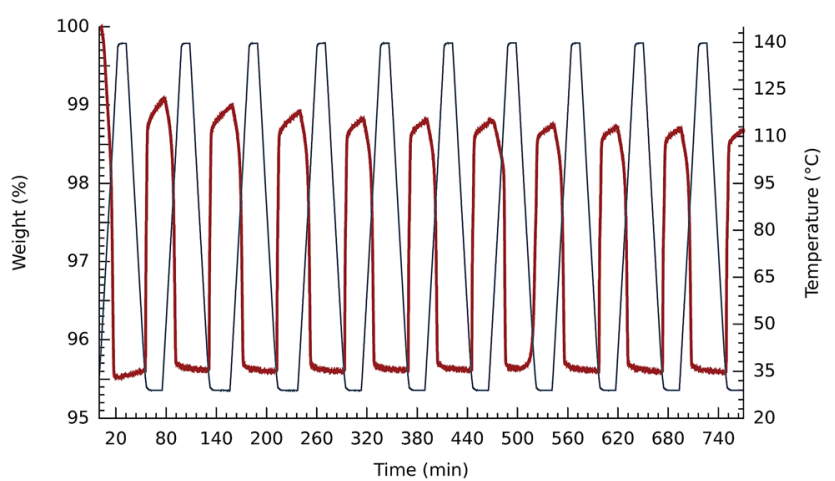

Fig. 2 Temperature dependent cycling of reversible $\mathrm{O}_{2}$ binding by $2 \mathrm{a}\left(\mathrm{BF}_{4}\right)_{4}$ measured using TGA.

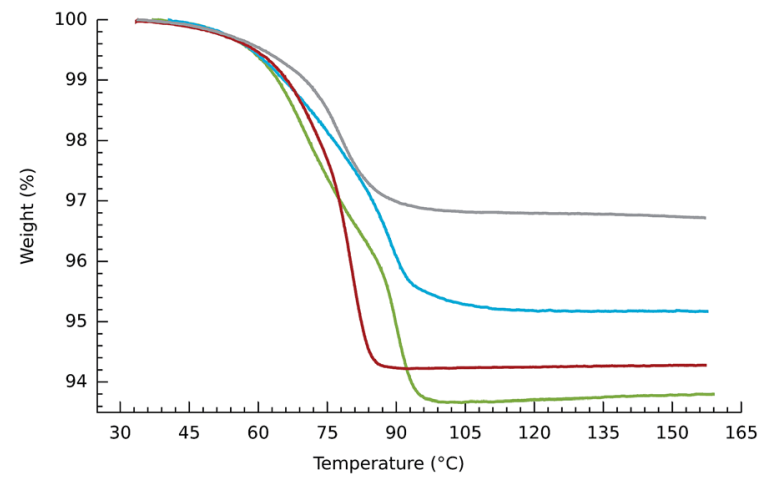

Fig. 3 TGA comparison for $\left[\left\{(\mathrm{bpbp}) \mathrm{CO}_{2}\left(\mathrm{O}_{2}\right)\right\}_{2}(\mathrm{bdcR})\right]\left(\mathrm{NO}_{3}\right)_{4} \cdot x \mathrm{H}_{2} \mathrm{O}$, bdcR $_{4}{ }^{2-}=\mathrm{Cl}_{2} \mathrm{bdc}^{2-}$ (red, 2c), bdc ${ }^{2-}$ (green, 2a), $\mathrm{NH}_{2} \mathrm{bdc}^{2-}$ (blue, 2b) and $\mathrm{F}_{4} \mathrm{bdc}^{2-}$ (grey, 2d) showing temperature difference in deoxygenation and dehydration.

$\mathrm{PF}_{6}{ }^{-}$salt is completely deoxygenated first at $160{ }^{\circ} \mathrm{C}$. Perhaps consistently, dioxygen resorption is significantly faster for the $\mathrm{PF}_{6}{ }^{-}$and $\mathrm{BF}_{4}{ }^{-}$salts where it is immediate upon exposure to air. Fig. 2 shows multiple cycles of $\mathrm{O}_{2}$ desorption and resorption into $2 \mathrm{a}\left(\mathrm{BF}_{4}\right)_{4}$ recorded over $13 \mathrm{~h}$. The first heating process results in a weight loss greater than the subsequent 9 cycles. This can be associated with loss of co-crystallized solvent. The formulation of one sample fits best to $2 \mathrm{a}\left(\mathrm{BF}_{4}\right)_{4} \cdot 5 \mathrm{H}_{2} \mathrm{O} \cdot \mathrm{MeOH}$ according to elemental analysis, so this is reasonable. Over the next 9 cycles we see only a marginal decrease in reversibility in $\mathrm{O}_{2}$ uptake for each cycle. The weight loss and gain on the final cycle amounts to a $92.9 \%$ yield if assuming that the sample is fully desolvated and deoxygenated, i.e., near stoichiometric. Resorption of $\mathrm{O}_{2}$ is significantly slower for the triflate and nitrate salts for which colour change from pink back to dark brown occurs over hours to days. The enthalpy of $\mathrm{O}_{2}$ binding to the structurally equivalent $\mathrm{Co}(\mathrm{II})_{2}$ sites should be almost identical for each complex, so the difference relates to inaccessibility of $\mathrm{O}_{2}$ binding sites, as reflected by slow kinetics.

Clearly the counteranions influence the $\mathrm{O}_{2}$ sorption/ desorption properties. Thus in our next experiments we kept the counteranion constant, choosing nitrate for which the slowest re-sorption of $\mathrm{O}_{2}$ was observed. We then chemically tweaked the supporting ligand system by varying substituents on the bridging di-carboxylato linkers, 2a-d. Our prediction, based on the solution chemistry of 1a-e was that by introducing electron withdrawing groups onto the supporting scaffold, we would lower the $\mathrm{O}_{2}$ affinity, further than that already achieved by using nitrate as a counteranion, potentially by orders of magnitude. We therefore expected that the nitrate salt of tetrafluoride substituted bdc $^{2-}$-bridged complex, 2d, would show the lowest $\mathrm{O}_{2}$ affinity of the series. For reference, the isolation of $\mathbf{1 e}$ required $-20{ }^{\circ} \mathrm{C}$ and an $\mathrm{O}_{2}$ atmosphere. ${ }^{11}$ The intention was to increase the chances for structural characterization of a deoxy form of these materials. Fig. 3 shows that the difference in $\mathrm{O}_{2}$ release temperatures of the series of nitrate salts of $2 \mathbf{a}-\mathbf{d}$ is, however, marginal. So this attempt at the rational design of the active molecular component of a functional solid state material did not meet our expectations and confirmed that aspects of 
crystal phase play a major role. The weight losses correspond to a minimum of stoichiometric loss of two $\mathrm{O}_{2}$ molecules per tetracobalt unit, however, the concurrent release of unknown amounts of solvent makes direct analysis difficult. Inflexion points in the weight loss curves for the materials containing $\mathbf{2 a}$, 2b and 2c would suggest the loss of two chemically different species consistent with water and $\mathrm{O}_{2}$. These losses occur just under $100{ }^{\circ} \mathrm{C}$ and distinguishing the order of loss has not been possible.

\section{Crystal structure of a deoxy complex}

The affinity of the $\mathrm{PF}_{6}{ }^{-}$salt of the complex $\mathbf{2} \mathbf{a}_{\text {deoxy }}$ towards $\mathrm{O}_{2}$ is approximately 10 times greater in the solid state compared to its $\mathrm{O}_{2}$ affinity in solution. In the absence of a crystal structure of the deoxy form of any member of this series, we attributed this effect to the formation of more reactive coordinatively unsaturated five-coordinated $\mathrm{Co}(\mathrm{II})$ sites on deoxygenation. Accordingly we assumed that the relative stabilization of the deoxy form in solution is due to solvent (acetonitrile, acetone or methanol) coordination to the Co(II) sites, which would then remain six coordinated. The solvent ligands would inhibit $\mathrm{O}_{2}$ binding in both dissociative and associative mechanisms. DFT calculations supported this hypothesis. ${ }^{\mathbf{1 0}}$

Although we have precipitated solid compounds for several members of series $\mathbf{1}$ and $\mathbf{2}$ and related hexacobalt systems under dioxygen-free atmospheres, ${ }^{\mathbf{1 4}}$ none of these air-sensitive materials have formed single crystals suitable for X-ray diffraction analysis. The increased stability of the nitrate and triflate salts of these deoxy complexes prompted further effort in this direction. We were, however, unable to grow single crystals of the compounds under anaerobic conditions using either $a b$ initio preparations, or crystallizations from deoxygenated solutions. Fortunately, upon careful heating to approximately $100{ }^{\circ} \mathrm{C}$, single crystals of $\left[\left\{(\mathrm{bpbp}) \mathrm{Co}_{2}\left(\mathrm{O}_{2}\right)\right\}_{2}\left(\mathrm{NH}_{2} \mathrm{bdc}\right)\right]\left(\mathrm{NO}_{3}\right)_{4} \cdot x \mathrm{H}_{2} \mathrm{O}$ $\left(2 \mathbf{b}\left(\mathrm{NO}_{3}\right)_{4} \cdot x \mathrm{H}_{2} \mathrm{O}\right)$ change colour from near black to reddish pink, with many of them remaining intact (Fig. 4). Cracking was observed in some crystals, especially larger specimens. This must be due to large strain caused by thermal stress and the molecular movement requisite for desolvation and deoxygenation. When cooled to room temperature and left exposed to oxygen, the crystals slowly reabsorb $\mathrm{O}_{2}$ over a period between 24

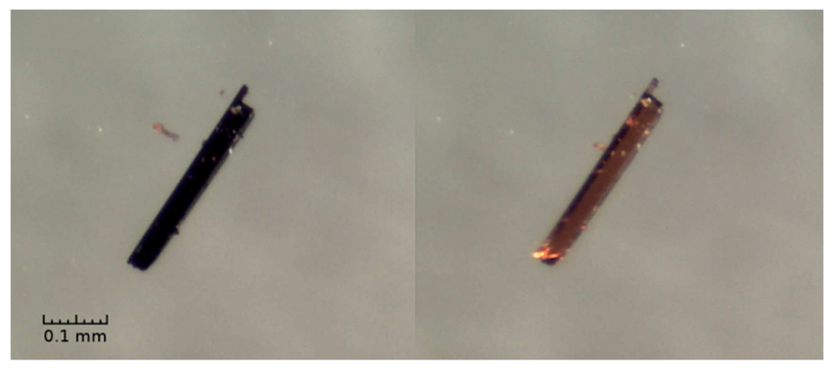

Fig. 4 Light microscope image of SC-to-SC deoxygenation of $\left[\left\{(\mathrm{bpbp}) \mathrm{CO}_{2}\left(\mathrm{O}_{2}\right)\right\}_{2}\left(\mathrm{NH}_{2} \mathrm{bdc}\right)\right]\left(\mathrm{NO}_{3}\right)_{4} \cdot 7 \mathrm{H}_{2} \mathrm{O}, \quad\left(2 \mathrm{~b}\left(\mathrm{NO}_{3}\right)_{4} \cdot 7 \mathrm{H}_{2} \mathrm{O}\right)$ (left) to give $\left[\left\{(\mathrm{bpbp}) \mathrm{CO}_{2}\left(\mathrm{NO}_{3}\right)\right\}_{2}\left(\mathrm{NH}_{2} \mathrm{bdc}\right)\right]\left(\mathrm{NO}_{3}\right)_{2} \cdot 2 \mathrm{H}_{2} \mathrm{O}, 2 \mathrm{~b}_{\text {deoxy }}\left(\mathrm{NO}_{3}\right)_{2} \cdot 2 \mathrm{H}_{2} \mathrm{O}$ (right). Transformation performed by heating for approximately 5 minutes on a regular hot-plate set to a temperature of $80^{\circ} \mathrm{C}$. and $48 \mathrm{~h}$ depending on size. Even during the resorption of oxygen many of the single crystals did not lose integrity. Through successive X-ray diffraction data collections on one single crystal as its oxy, then deoxy, then oxy form again, we can now not only report the first structure of a deoxy form of this type of complex, $\left[\left\{(\mathrm{bpbp}) \mathrm{Co}_{2}\left(\mathrm{NO}_{3}\right)\right\}_{2}\left(\mathrm{NH}_{2} \mathrm{bdc}\right)\right]\left(\mathrm{NO}_{3}\right)_{2} \cdot 2 \mathrm{H}_{2} \mathrm{O}$, $2 \mathbf{b}_{\text {deoxy }}\left(\mathrm{NO}_{3}\right)_{2} \cdot 2 \mathrm{H}_{2} \mathrm{O}$, but also that this material has formed by a remarkable single-crystal-to-single-crystal (SC-to-SC) transformation. It can then undergo a second equally remarkable SCto-SC to reform the oxy complex. Crystal structures were recorded in all three steps on one crystal, amounting to 1.5 desorption/sorption cycles and $2 \mathbf{b}_{\text {deoxy }}\left(\mathrm{NO}_{3}\right)_{2} \cdot 2 \mathrm{H}_{2} \mathrm{O}$ is the middle phase of a SC-to-SC-to-SC transformation (Table 1). Diffraction quality decreased over successive cycles, although visual inspection with a light microscope suggests that good crystals can repeat this process consecutively through at least 5 cycles. They will typically lose integrity, but not crystallinity, after a few cycles, making X-ray diffraction analysis using our machine impossible. Functionality is not lost since the resultant crystalline powders can still reversibly bind $\mathrm{O}_{2}$.

Crystals of $2 \mathbf{b}\left(\mathrm{NO}_{3}\right)_{4} \cdot x \mathrm{H}_{2} \mathrm{O}$ are weakly diffracting, leading to low quality intensity data, and considerable disorder in both cocrystallized solvent molecules and nitrate counteranions is observed. After heating and the structure of the resultant pink deoxy form had been determined, this same crystal was carefully placed in a drop of Fomblin ${ }^{\circledR} \mathrm{Y}$ oil on a microscope slide and left for $48 \mathrm{~h}$ whereupon it converted back to the dark colour. Another data set was collected and the re-formation of the $2 \mathbf{b}\left(\mathrm{NO}_{3}\right)_{4} \cdot 7 \mathrm{H}_{2} \mathrm{O}$ verified. The structures of the cations in $2 \mathbf{b}\left(\mathrm{NO}_{3}\right)_{4} \cdot 7 \mathrm{H}_{2} \mathrm{O}$ and $2 \mathbf{b}_{\text {deoxy }}\left(\mathrm{NO}_{3}\right)_{2} \cdot 2 \mathrm{H}_{2} \mathrm{O}$ are shown in Fig. $5 \mathrm{a}$ and $\mathrm{b}$ respectively. Important distances and angles are given in Table 2.

The peroxide ligand is, as expected, absent in the deoxy form. The surprise to us was that the Co(II) ions are still six coordinated. Two of the formally counter anionic nitrate ions are now coordinated in a bridging mode. The coordinated nitrates and peroxo ligands of the deoxy and oxy forms respectively are located on opposite sides of the plane formed by the $\mathrm{Co}_{4}\left(\mathrm{NH}_{2}\right.$ bdc $)$ unit. Although impossible to decipher which two of the four nitrate anions move and become coordinated in the deoxy form, it is reasonable to assume that it is those in closest proximity to the binding sites at each end of the molecule. A comparison of the oxy and deoxy structures suggest that the translational movement needed for the pertinent $\mathrm{O}$ atoms of the closest nitrate ions to each end of the molecule are between 46 A. These closest nitrate oxygen atoms (those associated with $\mathrm{N} 14$ and N15) to each dinuclear site are located on the opposite side of the molecule from each other (as defined by the plane of the linking aminobenzene ring). The $\mathrm{O}_{\mathrm{NO}_{3}} \cdots \mathrm{Co}$ distances are

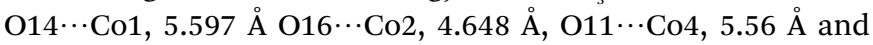

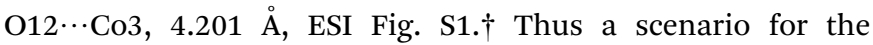
deoxygenation reaction mechanism of a $\mathrm{SN}_{2}$ type reaction at each Co ion where the nitrates push the $\mathrm{O}_{2}$ release can be envisaged. This scenario involves some donor atom slipping and movement of the supporting ligands. An impression of the movement of the atoms of the dinucleating ligand can be seen in the overlay of $\mathbf{2} \mathbf{b}$ and $\mathbf{2} \mathbf{b}_{\mathbf{d e o x y}}$ in ESI Fig. S2. $\dagger$ Relative to the 
Table 1 Selected crystallographic data collected on a single crystal after the second and third phase transition

\begin{tabular}{|c|c|c|}
\hline & {$\left[\left\{(\mathrm{bpbp}) \mathrm{Co}_{2}\left(\mathrm{O}_{2}\right)\right\}_{2}\left(\mathrm{NH}_{2} \mathrm{bdc}\right)\right]\left(\mathrm{NO}_{3}\right)_{4} \cdot 7 \mathrm{H}_{2} \mathrm{O}$} & {$\left[\left\{(\mathrm{bpbp}) \mathrm{Co}_{2}\left(\mathrm{NO}_{3}\right)\right\}_{2}\left(\mathrm{NH}_{2} \mathrm{bdc}\right)\right]\left(\mathrm{NO}_{3}\right)_{2} \cdot 2 \mathrm{H}_{2} \mathrm{O}$} \\
\hline Empirical formula & $\mathrm{C}_{80} \mathrm{H}_{97} \mathrm{Co}_{4} \mathrm{~N}_{17} \mathrm{O}_{29}$ & $\mathrm{C}_{80} \mathrm{H}_{87} \mathrm{Co}_{4} \mathrm{~N}_{17} \mathrm{O}_{20}$ \\
\hline Formula weight $\left(\mathrm{g} \mathrm{mol}^{-1}\right)$ & 1996.48 & 1842.41 \\
\hline Crystal system & Triclinic & Triclinic \\
\hline Space group & $P \overline{1}$ & $P \overline{1}$ \\
\hline$a(\AA)$ & $10.1905(13)$ & $10.8710(9)$ \\
\hline$\alpha\left({ }^{\circ}\right)$ & $115.123(4)$ & $64.984(2)$ \\
\hline$\beta\left(^{\circ}\right)$ & $92.484(5)$ & $86.763(4)$ \\
\hline$\gamma\left(\left(^{\circ}\right)\right.$ & $99.306(5)$ & $79.326(3)$ \\
\hline Volume $\left(\AA^{3}\right)$ & $4207.3(10)$ & $4290.0(6)$ \\
\hline$Z$ & 2 & 2 \\
\hline$\rho_{\text {calc }}\left(\mathrm{mg} \mathrm{mm}^{-3}\right)$ & 1.562 & 1.421 \\
\hline Index ranges & $-11 \leq h \leq 11,-24 \leq k \leq 20,-25 \leq l \leq 25$ & $-12 \leq h \leq 11,-22 \leq k \leq 24,-25 \leq l \leq 25$ \\
\hline Reflections collected & 40936 & 50854 \\
\hline Independent reflections & $14235\left(R_{\text {int }}=0.0498\right)$ & $15069\left(R_{\text {int }}=0.0483\right)$ \\
\hline Data/restraints/parameters & $14235 / 37 / 1168$ & 15 069/0/1115 \\
\hline GooF on $F^{2}$ & 1.075 & 1.062 \\
\hline Final $R_{1}(F)^{a}(I>2 \sigma(I)) / \mathrm{w} R_{2}\left(F^{2}\right)^{b}$ & $0.1007 / 0.2604$ & $0.1024 / 0.2499$ \\
\hline$R_{1}^{a} / \mathrm{w} R_{2}\left(F^{2}\right)^{b}$ (all data) & $0.1525 / 0.2960$ & $0.1547 / 0.2820$ \\
\hline Largest diff. peak/hole/e $\AA^{-3}$ & $1.80 /-1.33$ & $2.43 /-0.92$ \\
\hline
\end{tabular}
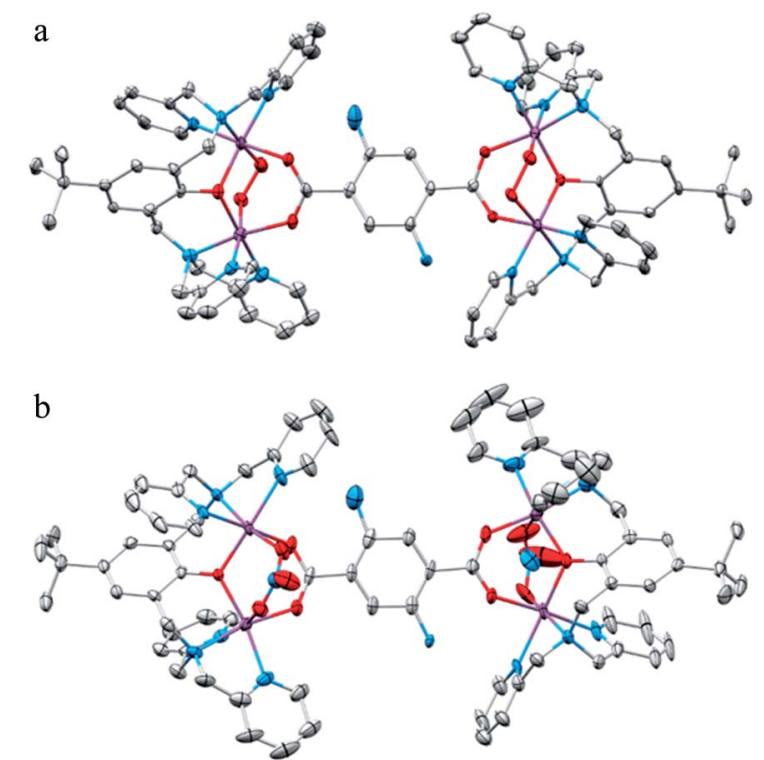

Fig. 5 Molecular structure of the cations in (a) $\left[\left\{(\mathrm{bpbp}) \mathrm{CO}_{2}\left(\mathrm{O}_{2}\right)\right\}_{2^{-}}\right.$ $\left.\left(\mathrm{NH}_{2} \mathrm{bdc}\right)\right]\left(\mathrm{NO}_{3}\right)_{4} \cdot 7 \mathrm{H}_{2} \mathrm{O}, \quad 2 \mathrm{~b}\left(\mathrm{NO}_{3}\right)_{4} \cdot 7 \mathrm{H}_{2} \mathrm{O}, \quad$ (b) $\quad\left[\left\{(\mathrm{bpbp}) \mathrm{Co}_{2}(\mathrm{~N}-\right.\right.$ $\left.\left.\left.\mathrm{O}_{3}\right)\right\}_{2}\left(\mathrm{NH}_{2} \mathrm{bdc}\right)\right]\left(\mathrm{NO}_{3}\right)_{2} \cdot 2 \mathrm{H}_{2} \mathrm{O}, \quad 2 \mathrm{~b}_{\text {deoxy }}\left(\mathrm{NO}_{3}\right)_{2} \cdot 2 \mathrm{H}_{2} \mathrm{O}$. Two amine nitrogen atoms are shown on the 2-aminoterephtalato linker due a $50 \%$ occupancy in both positions. Hydrogen atoms omitted for clarity. Anisotropic displacement parameters drawn at the $30 \%$ probability level.
Table 2 Selected bond distances (Å) within one of the two dimetallic centers

$\begin{array}{lll} & & \\ & & \\ & & \\ & & \\ \mathrm{Co} 1-\mathrm{O} 1 & \left.\mathrm{NO}_{3}\right)_{4} \cdot 7 \mathrm{H}_{2} \mathrm{O} & 2 \mathbf{b}_{\text {deoxy }}\left(\mathrm{NO}_{3}\right)_{2} \cdot 2 \mathrm{H}_{2} \mathrm{O} \\ \mathrm{Co} 2-\mathrm{O} 1 & 1.895(6) & 1.996(5) \\ \mathrm{Co} 1-\mathrm{O} 7\left(\mathrm{O}_{2}{ }^{2-} / \mathrm{NO}_{3}{ }^{-}\right)^{a} & 1.894(7) & 2.011(5) \\ \mathrm{Co} 2-\mathrm{O} 8\left(\mathrm{O}_{2}{ }^{2-} / \mathrm{NO}_{3}{ }^{-}\right)^{a} & 1.011(5) & 2.271(6) \\ \mathrm{Co} 1-\mathrm{O} 3 & 1.934(6) & 2.100(6) \\ \mathrm{Co} 2-\mathrm{O} 4 & 1.904(6) & 1.990(5) \\ \mathrm{O} 7-\mathrm{O} 8\left(\mathrm{O}_{2}{ }^{2-} / \mathrm{NO}_{3}{ }^{-}\right)^{a} & 1.416(9) & 2.106(5) \\ \mathrm{Co} 1-\mathrm{Co} 2 & 3.164(2) & 2.212(9) \\ \end{array}$

${ }^{a} \mathrm{O} 7$ and $\mathrm{O} 8$ belong to $\mathrm{O}_{2}{ }^{2-}$ or bridging $\mathrm{NO}_{3}{ }^{-}$. For a full list of bond distances and angles see ESI Table S1.

movement of $\mathrm{O}_{2}$, nitrate and water, this must be a minor rattling for the crystals. It does not, however, lessen the impressiveness of the SC-to-SC transformations observed. The distance between the nitrate coordinated oxygen atoms are on average 2.185(7) $\AA$, whereas the $\mathrm{O}-\mathrm{O}$ bond distance is av. 1.423(9) Å. The Co(II)-Co(II) distance in $2 \mathbf{b}_{\text {deoxy }}$ averages $3.448(2)$ $\AA$, and this is shortened to a $\mathrm{Co}(\mathrm{III})-\mathrm{Co}(\mathrm{III})$ distance of av. 3.171(2) $\AA$ in the oxygenated form, 2 b. This difference is due to 
the bite of the $s y n-\mu_{2}-$ nitrate ${ }^{2-} v s$. that of $s y n-\mu_{2}-\mathrm{O}_{2}{ }^{2-}$, the respective metal ion radii, and the more powerful geometric preference for the $\mathrm{Co}(\mathrm{III})$ system to show a regular octahedral geometry. Chemically, each end of $\mathbf{2 b}$ and $\mathbf{2} \mathbf{b}_{\text {deoxy }}$ is different due to the single amine group ortho to one of the carboxylato groups in the linker 2-aminoterephthalato ligand. In both of the structures this amine group is disordered approximately equally over the two positions para to each other (both positions depicted in Fig. 5). There is H-bonding between the $\mathrm{NH}_{2} \mathrm{bdc}^{2-}$ amine group and the adjacent coordinated carboxylato oxygen atom $\left(\mathrm{O} \cdots \mathrm{N}=2717 \AA, 2.808 \AA\right.$ in $2 \mathbf{a}_{\text {deoxy }} 2.697 \AA$, $2.723 \AA$ in $\left.2 \mathbf{a}\right)$.

Inspection of unit cell sizes reveals that the crystal lattice expands by around $2 \%$ when it expels $\mathrm{O}_{2}$. This is surprising given that the material is being converted from a tetracation to a dianion with correspondingly four and two counter nitrates respectively, and a lower water content in the deoxy from. The calculated void space in fully desolvated models of $2 \mathbf{b}\left(\mathrm{NO}_{3}\right)_{4} \cdot 7 \mathrm{H}_{2} \mathrm{O}$ and $2 \mathbf{b}_{\text {deoxy }}\left(\mathrm{NO}_{3}\right)_{2} \cdot 2 \mathrm{H}_{2} \mathrm{O}$ using a probe radius of $1.2 \AA$ are $4.8 \%$ and $7.0 \%$ respectively. Another possible contributing factor for the relatively slow uptake of $\mathrm{O}_{2}$ by the nitrate salt is that the voids do not form channels in $\mathbf{2} \mathbf{b}_{\mathbf{d e o x}}{ }^{-}$ $\left(\mathrm{NO}_{3}\right)_{2} \cdot 2 \mathrm{H}_{2} \mathrm{O}$. By contrast they do in $2 \mathbf{b}\left(\mathrm{NO}_{3}\right)_{4} \cdot 7 \mathrm{H}_{2} \mathrm{O}$. This might facilitate the desorption process. If the probe radius is expanded to $1.6 \AA$ for $2 \mathbf{b}\left(\mathrm{NO}_{3}\right)_{4} \cdot 7 \mathrm{H}_{2} \mathrm{O}$ and $1.9 \AA$ for $2 \mathbf{b}_{\mathbf{d e o x y}^{-}}$ $\left(\mathrm{NO}_{3}\right)_{2} \cdot 2 \mathrm{H}_{2} \mathrm{O}$ the void space effectively becomes $0 \%$ in both structures (calculated within the Mercury CSD 3.1.1 suite from $\left.\mathrm{CCDC}^{15,16}\right)$. The kinetic diameter of $\mathrm{O}_{2}$ is $3.46 \AA^{17}$ See ESI Fig. S6-S9† for impressions of voids/pseudo voids. These facts suggest an active transport mechanism for the $\mathrm{O}_{2}$ where conduit voids are not actually essential for sorption/desorption. We have shown that significant atomic movement is possible in the crystals and we conclude that the $\mathrm{O}_{2}$ hops between the chemisorptive binding sites. The pronounced structural flexibility observed here upon guest desorption is reminiscent of that seen in a range of other discrete supramolecular host materials, ${ }^{18,19}$ in which retention of monocrystallinity occurs despite the rather extreme requirements that guest molecule migration and structural transformation place on the host crystal. Host materials have been shown to undergo phase transitions from non-porous to porous on uptake of $\mathrm{CO}_{2} \cdot{ }^{19} \mathrm{Of}$ particular note here is that the system retains crystallinity with the migration and subsequent binding of nitrate anions on the dinuclear Co(II) sites (see ESI Fig. S2(b) $\dagger$ for molecular overlays showing the resulting distortion of the discrete tetranuclear host).

The hydrogen bonding interaction of the amine group with the coordinated carboxylate at one end of the molecule might be expected to modulate the $\mathrm{O}_{2}$ binding affinity of this end such that the semioxy intermediate, $\left[(\mathrm{bpbp}) \mathrm{Co}_{2}\left(\mathrm{NO}_{3}\right)\left(\mathrm{NH}_{2} \mathrm{bdc}\right)(\mathrm{bpbp})-\right.$ $\left.\mathrm{Co}_{2}\left(\mathrm{O}_{2}\right)\right]\left(\mathrm{NO}_{3}\right)_{3}$, is thermally stable at intermediate temperatures. We have, however, not found conditions by which we can detect this putative species during attempts to follow the single crystal structure of a sorbing crystal. We note that the temperature dependent cycling of reversible $\mathrm{O}_{2}$ binding by $2 \mathbf{b}\left(\mathrm{BF}_{4}\right)_{4}$ (Fig. S10†) shows yields decrease marginally more on each successive cycle compared to $2 \mathbf{a}\left(\mathrm{NO}_{3}\right)_{4}$ (Fig. 2). It seems obvious to speculate that the $\mathrm{BF}_{4}{ }^{-}$ions do not interact with the $\mathrm{Co}(\mathrm{II})_{2}$

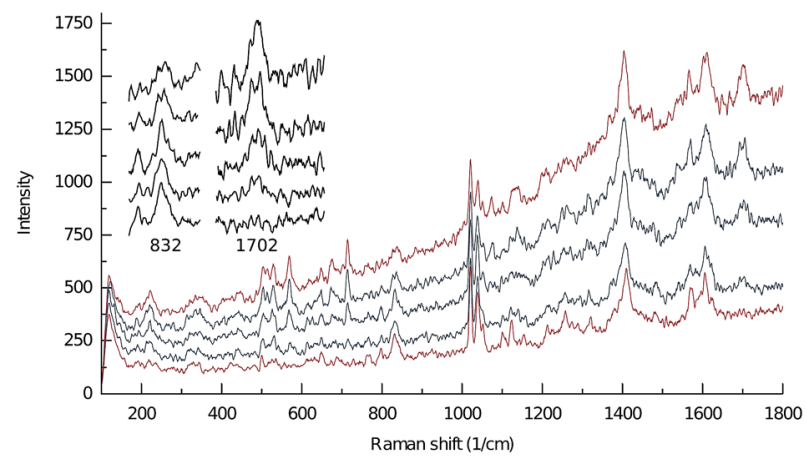

Fig. 6 Raman spectra from 100 to $1800 \mathrm{~cm}^{-1}$ following thermal deoxygenation of $\left[\left\{(\mathrm{bpbp}) \mathrm{CO}_{2}\left(\mathrm{O}_{2}\right)_{2}\right\}\left(\mathrm{NH}_{2} \mathrm{bdc}\right)\right]\left(\mathrm{NO}_{3}\right)_{4} \cdot 7 \mathrm{H}_{2} \mathrm{O}$, $2 \mathrm{~b}\left(\mathrm{NO}_{3}\right)_{4} \cdot 7 \mathrm{H}_{2} \mathrm{O}$ at $20{ }^{\circ} \mathrm{C}, 70{ }^{\circ} \mathrm{C}, 90{ }^{\circ} \mathrm{C}, 100{ }^{\circ} \mathrm{C}$ and $120{ }^{\circ} \mathrm{C}$ (from bottom to top).

sites as intimately as $\mathrm{NO}_{3}{ }^{-}$. Thus on $\mathrm{O}_{2}$ desorption lattice water coordinates to the resultant $\mathrm{Co}$ (II) ions. If the aquo ligands of these putative $\left\{\mathrm{Co}(\mathrm{II})\left(\mathrm{OH}_{2}\right)\right\}_{2}$ motifs cannot be substituted by $\mathrm{O}_{2}$ during its oxidative sorption, "met" $\mathrm{Co}_{2}{ }^{\mathrm{III}}$ sites containing aquo and hydoxo ligands will result through an outersphere oxidation process. We have observed previously that reduction of complexes with this $\mathrm{H}$-bonded $\mathrm{Co}^{\mathrm{III}}(\mathrm{HOHOH}) \mathrm{Co}^{\mathrm{III}}$ motif is not favorable ${ }^{13}$ thus the active sites will be poisoned.

\section{Vibrational spectroscopy}

The solid state transformations between $2 \mathbf{b}\left(\mathrm{NO}_{3}\right)_{4} \cdot 7 \mathrm{H}_{2} \mathrm{O}$ and $2 \mathbf{b}_{\text {deoxy }}\left(\mathrm{NO}_{3}\right)_{2} \cdot 2 \mathrm{H}_{2} \mathrm{O}$ can be observed using resonance Raman and IR spectroscopies (Fig. 6 and 7, respectively). Specifically, the band at $840 \mathrm{~cm}^{-1}$, assigned to the $\mathrm{O}-\mathrm{O}$ stretch, is much reduced in the resonance Raman spectra when $2 \mathbf{b}\left(\mathrm{NO}_{3}\right)_{4} \cdot 7 \mathrm{H}_{2} \mathrm{O}$ is heated. During this process new bands associated with the coordinated bridging nitrate at 570,710 and $1700 \mathrm{~cm}^{-1}$ grow in.

IR spectra show that water is lost in the first heating of $2 \mathbf{b}\left(\mathrm{NO}_{3}\right)_{4} \cdot 7 \mathrm{H}_{2} \mathrm{O}$ as the broad band between 3000 and $3500 \mathrm{~cm}^{-1}$ reduces significantly, see SI Fig. S3. $\dagger$ Otherwise the most significant changes occur between 800 and $1000 \mathrm{~cm}^{-1}$ and these can predominantly be associated with changes in the $\mathrm{N}-\mathrm{O}$ bond strength within the nitrate ions, especially those moving from coordinated to non-coordinated positions. The two coordinated

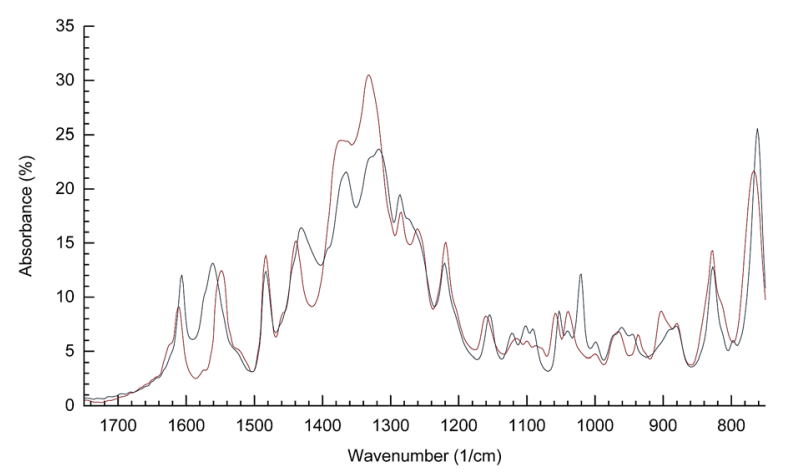

Fig. 7 FT-IR spectra from $1650 \mathrm{~cm}^{-1}$ to $850 \mathrm{~cm}^{-1}$ of $2 \mathrm{~b}_{\text {deoxy }}\left(\mathrm{NO}_{3}\right)_{2} \cdot 2 \mathrm{H}_{2} \mathrm{O}, \mathrm{T}=120^{\circ} \mathrm{C}(\mathrm{red})$ and $2 \mathrm{~b}\left(\mathrm{NO}_{3}\right)_{4} \cdot 7 \mathrm{H}_{2} \mathrm{O}, \mathrm{T}=-20^{\circ} \mathrm{C}$ (black). 
nitrates can be expected to be chemically different due to the presence of the amine adjacent to one of these and this will smear the spectra further. A small difference in the $\nu_{\text {as }}(c a .1570$ $\mathrm{cm}^{-1}$ ) and $\nu_{\mathrm{s}}\left(c a .1440 \mathrm{~cm}^{-1}\right)$ due to the bridging carboxylato bands of the $\mathrm{NH}_{2} \mathrm{bdc}^{2-}$ unit can be seen in the IR spectra of the oxy and deoxy forms. This is rationalized mainly by the observed changes in the $\mathrm{C}-\mathrm{O}$ bond distances in the $\mathrm{Co}$ (II) and $\mathrm{Co}$ (III) complexes.

\section{Conclusions}

With the cleavage offour bonds, and the creation offour bonds in one molecule/cation, the complete evacuation and selective uptake of a diatomic gas, atom movements by up to $7 \AA$ A of anions, hydration changes and donor atom sliding, the successive SC-toSC-to-SC transformations we have followed by single crystal Xray diffraction are remarkable. Although several impressive examples of SC-to-SC transformations are known, ${ }^{\mathbf{1 8 - 2 0}}$ to our knowledge none undergo such extensive atom movements, bond cleavage and formation and reversibility with gas sorption and desorption.

Previously we had speculated that the active site of $2 \mathbf{a}_{\text {deoxy }}\left(\mathrm{PF}_{6}\right)_{4}$ in the solid state was coordinatively unsaturated and that this accounted for a higher affinity, by an order of magnitude, for $\mathrm{O}_{2}$ compared to when $\mathbf{2} \mathbf{a}_{\text {deoxy }}$ is dissolved and hence having solvent molecules occupying the sixth position. ${ }^{8}$ The present work shows this assumption may not be entirely correct: The respective degrees of association of the counteranions of the series with the Co(II) atoms of the deoxy forms play a major role in determining reaction rates of sorption and desorption processes. Nitrate is the strongest donor of the counteranions selected in this study, thus it will form the strongest interaction (formally coordination) with the metal ions. The fluorinated anions, typically regarded as non-coordinating or very weakly coordinating, ${ }^{21}$ are presumably more weakly associated with the metal centers in the deoxy forms, if they move at all during the sorption/desorption processes.

In the solid state this series of compounds show $\mathrm{O}_{2}$ binding affinities and reversibility which rival that of myoglobin. We have found, however, that crystal structure plays a far greater role in tuning these properties compared with the electronic tuning possible through the introduction of substituents on the linker dicarboxylate unit. BET measurements of $2 \mathbf{a}_{\mathbf{d e o x y}}\left(\mathrm{PF}_{6}\right)_{4}$ had indicated that this material was non-porous. ${ }^{8}$ This result, along with the calculated insufficient void space in $2 \mathbf{b}_{\text {deoxy }}\left(\mathrm{NO}_{3}\right)_{2} \cdot 2 \mathrm{H}_{2} \mathrm{O}$ for physisorbing $\mathrm{O}_{2}$ implies that the $\mathrm{O}_{2}$ molecules are actively transported through the crystalline phases of these materials: a biomimetic chemisorptive hopping mechanism of the $\mathrm{O}_{2}$ molecules from $\mathrm{Co}_{2}$ site to $\mathrm{Co}_{2}$ site can be imagined. This will require considerable molecular flexibility, molecule and nitrate ion movement, yet crystallinity is retained.

\section{Experimental}

ESI-MS spectra were recorded on a Bruker microTOF-QII. Thermogravimetric analysis was performed on a PerkinElmer TGA 4000. Samples were heated from $30{ }^{\circ} \mathrm{C}$ to $140{ }^{\circ} \mathrm{C}$ at
$5{ }^{\circ} \mathrm{C} \mathrm{min}{ }^{-1}$ under a stream of $\mathrm{N}_{2}\left(20.0 \mathrm{~mL} \mathrm{~min}^{-1}\right)$. Cooling was done at same rate under a stream of $\mathrm{O}_{2}\left(20.0 \mathrm{~mL} \mathrm{~min}^{-1}\right)$. VT-IR measurements were collected from $25^{\circ} \mathrm{C}$ up to $240{ }^{\circ} \mathrm{C}$ (ramping and then holding at each temperature) and then back down again to RT using a Bruker FT-IR spectrometer with ATR attachment. VT-Raman was performed between $-20{ }^{\circ} \mathrm{C}$ and $120^{\circ} \mathrm{C}$ using a Renishaw Raman in Via Reflex spectrometer (514 $\mathrm{nm}$ laser). Elemental microanalyses were performed at the Department of Chemistry, University of Copenhagen, Denmark. Single crystal data were collected with a Bruker-Nonius X8 Kappa Apex II at $150 \mathrm{~K}$ using Mo K $\alpha$ radiation $(\lambda=0.71073 \AA)$. Semi-empirical absorption corrections were applied using SADABS. ${ }^{22}$ Initial models were obtained with SHELXS-2013 using Direct Methods and further refined with SHELXL-2013. ${ }^{23}$ Hydrogen atoms on $\mathrm{C}$ atoms were placed at calculated positions and allowed to ride during refinement with $U_{\text {iso }}(\mathrm{H})=1.5 U_{\text {eq }}$ when connected to methyl groups and $U_{\text {iso }}(\mathrm{H})=1.2 U_{\text {eq }}$ for others. Hydrogen atoms connected to heteroatoms were not located in different Fourier maps and were excluded in the refinement. $\left[\left\{\mathrm{Co}_{2}(\mathrm{bpbp})\left(\mathrm{O}_{2}\right)\right\}_{2}(\mathrm{bdc})\right]\left(\mathrm{PF}_{6}\right)_{4} \cdot 3 \mathrm{H}_{2} \mathrm{O}\left(2 \mathrm{a}\left(\mathrm{PF}_{6}\right)_{4} \cdot 3 \mathrm{H}_{2} \mathrm{O}\right)$ and $\mathrm{bpbpH}$ were prepared as previously reported. ${ }^{\mathbf{8 , 2 4}}$

\section{Synthesis}

$\left[\left\{\mathrm{Co}_{2}(\mathrm{bpbp})\left(\mathrm{O}_{2}\right)\right\}_{2}(\mathrm{bdc})\right]\left(\mathrm{BF}_{4}\right)_{4} \cdot \mathbf{5} \mathrm{H}_{2} \mathrm{O} \cdot \mathrm{MeOH} \quad\left(2 \mathrm{a}\left(\mathrm{BF}_{4}\right)_{4} \cdot\right.$ $\left.\mathbf{5} \mathbf{H}_{2} \mathbf{O} \cdot \mathbf{M e O H}\right)$. A solution of sodium 1,4-benzenedicarboxylate ( $\mathrm{Na}_{2}$ bdc; $55.0 \mathrm{mg}, 0.26 \mathrm{mmol}$ ) was dissolved in $\mathrm{H}_{2} \mathrm{O}(10 \mathrm{~mL})$ and added dropwise to a solution of $\mathrm{Co}\left(\mathrm{BF}_{4}\right)_{2} \cdot 6 \mathrm{H}_{2} \mathrm{O}(356.7 \mathrm{mg}, 1.05$ $\mathrm{mmol})$ and bpbpH $(299.8 \mathrm{mg}, 0.52 \mathrm{mmol})$ in acetone- $\mathrm{MeOH}$ $(1: 1,50 \mathrm{~mL})$. Slow evaporation of the resulting dark brown solution yielded black needle-like crystals which were collected by filtration, washed with ice cold $\mathrm{H}_{2} \mathrm{O}(3 \times 5 \mathrm{~mL})$ and air-dried (289.7 mg, $0.15 \mathrm{mmol}, 57.0 \%$ ). Anal. calcd (found) for $\mathrm{C}_{81} \mathrm{H}_{96} \mathrm{~B}_{4} \mathrm{Co}_{4} \mathrm{~F}_{16} \mathrm{~N}_{12} \mathrm{O}_{16}$ (2076.65 $\left.\mathrm{g} \mathrm{mol}^{-1}\right): \mathrm{C}, 46.85$ (46.19); $\mathrm{H}$, 4.66 (4.20); N, 8.09 (7.98)\%. ESI-MS (MeCN, pos. mode) calcd (found) $m / z=427.10 \quad\left(427.10, \quad\left[\mathrm{Co}_{2}(\mathrm{bpbp})(\mathrm{bdc})\right]^{2+}\right.$, $\mathrm{C}_{44} \mathrm{H}_{44} \mathrm{Co}_{2} \mathrm{~N}_{6} \mathrm{O}_{5}, 100 \%$ ). IR (FT-ATR diamond anvil) $\nu / \mathrm{cm}^{-1}=$ 1611 (m), 1554 (m), 1482 (m), 1439 (m), 1385 (s), 1313 (w), 1285 (m), $1265(\mathrm{w}), 1222(\mathrm{~m}), 1161(\mathrm{w}), 1041(\mathrm{~s}), 935(\mathrm{~m}), 874(\mathrm{~m}), 824$ (m), $770(\mathrm{~s}), 736(\mathrm{~m}), 714(\mathrm{~m}), 696(\mathrm{w}), 519(\mathrm{~m}), 458(\mathrm{~s})$.

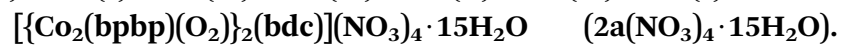
Prepared as above but using $\mathrm{Co}\left(\mathrm{NO}_{3}\right)_{2} \cdot 6 \mathrm{H}_{2} \mathrm{O}$ yielding black needle-like crystals (370.2 mg, $0.20 \mathrm{mmol}, 76.7 \%)$. Anal. calcd (found) for $\mathrm{C}_{80} \mathrm{H}_{114} \mathrm{Co}_{4} \mathrm{~N}_{16} \mathrm{O}_{38}\left(2143.60 \mathrm{~g} \mathrm{~mol}^{-1}\right)$ : $\mathrm{C}, 44.83$ (44.63); H, 5.36 (4.22); N, 10.45 (10.26)\%. ESI-MS (MeCN, pos. mode) calcd (found) $\mathrm{m} / z=427.10\left(427.10,\left[\mathrm{Co}_{2}(\mathrm{bpbp})(\mathrm{bdc})\right]^{2+}\right.$, $\mathrm{C}_{44} \mathrm{H}_{44} \mathrm{Co}_{2} \mathrm{~N}_{6} \mathrm{O}_{5}, 100 \%$ ). IR (FT-ATR diamond anvil) $\nu / \mathrm{cm}^{-1}=$ 1611 (m), 1554 (s), 1487 (s), 1430 (m), 1324 (s), 1218 (s), 1157 (m), 1109 (w), $1055(\mathrm{~m}), 1039(\mathrm{~m}), 969(\mathrm{w}), 937(\mathrm{w}), 903(\mathrm{w}), 876$ (m), $827(\mathrm{~s}), 763(\mathrm{~s}), 741(\mathrm{~s}), 720(\mathrm{~m})$.

$\left[\left\{\mathrm{Co}_{2}(\mathrm{bpbp})\left(\mathrm{O}_{2}\right)\right\}_{2}(\mathrm{bdc})\right](\mathrm{OTf})_{4} \cdot \mathbf{5} \mathrm{H}_{2} \mathrm{O} \quad\left(2 \mathrm{a}(\mathrm{OTf})_{4} \cdot \mathbf{5} \mathrm{H}_{2} \mathrm{O}\right)$. Prepared as above but from $\mathrm{Co}(\mathrm{OTf})_{2}$ yielding black needle-like crystals (273.1 mg, $0.12 \mathrm{mmol}, 47.7 \%$ ). Anal. calcd (found) for $\mathrm{C}_{84} \mathrm{H}_{0} \mathrm{Co}_{4} \mathrm{~F}_{12} \mathrm{~N}_{12} \mathrm{O}_{27} \mathrm{~S}_{4}$ (2293.67 $\mathrm{g} \mathrm{mol}^{-1}$ ): C, 43.99 (43.91); $\mathrm{H}$, 4.04 (3.59); N, 7.33 (7.27)\%. ESI-MS (MeCN, pos. mode) calcd (found) $m / z=427.10 \quad\left(427.10, \quad\left[\mathrm{Co}_{2}(\mathrm{bpbp})(\mathrm{bdc})\right]^{2+}\right.$, $\mathrm{C}_{44} \mathrm{H}_{44} \mathrm{Co}_{2} \mathrm{~N}_{6} \mathrm{O}_{5}, 65 \%$ ), IR (FT-ATR diamond anvil) $\nu / \mathrm{cm}^{-1}=$ 
1606 (w), 1543 (m), 1484 (m), 1432 (w), 1383 (m), 1254 (s), 1218 (m), 1139 (m), $1059(\mathrm{w}), 1028(\mathrm{~s}), 879(\mathrm{w}), 822(\mathrm{~m}), 763$ (s), 718 (w), $653(\mathrm{~s}), 569(\mathrm{~m}), 512(\mathrm{~s})$.

$\left[\left\{\mathrm{Co}_{2}(\mathrm{bpbp})\left(\mathrm{O}_{2}\right)\right\}_{2}\left(\mathrm{NH}_{2} \mathrm{bdc}\right)\right]\left(\mathrm{NO}_{3}\right)_{4} \cdot \mathbf{1 1 H}_{2} \mathrm{O}\left(2 \mathrm{~b}\left(\mathrm{NO}_{3}\right)_{4} \cdot \mathbf{1 1 H}_{2} \mathrm{O}\right)$. 2-Aminoterephthalic acid $(102.0 \mathrm{mg}, 0.56 \mathrm{mmol})$ was added to a solution of $\mathrm{NaOH}$ (45.0 mg, $1.13 \mathrm{mmol}, 2$ eq.) in $\mathrm{H}_{2} \mathrm{O}(25 \mathrm{~mL})$ and the mixture was gently heated until a clear solution formed whereupon it was added dropwise to a mixture of $\mathrm{Co}\left(\mathrm{NO}_{3}\right)_{2} \cdot 6 \mathrm{H}_{2} \mathrm{O}$ (655.5 $\mathrm{mg}, 2.25 \mathrm{mmol})$ and bpbpH (645.0 $\mathrm{mg}, 1.13 \mathrm{mmol})$ in acetone-MeOH (2:1, $75 \mathrm{~mL})$. Slow evaporation of the resulting dark brown solution yielded black needle-like crystals which were collected by filtration, washed with ice cold $\mathrm{H}_{2} \mathrm{O}(3 \times 5 \mathrm{~mL})$ and air-dried (979.3 mg, $0.52 \mathrm{mmol}, 93.5 \%)$. Anal. calcd (found) for $\mathrm{C}_{80} \mathrm{H}_{105} \mathrm{Co}_{4} \mathrm{~N}_{17} \mathrm{O}_{33}\left(2068.52 \mathrm{~g} \mathrm{~mol}^{-1}\right): \mathrm{C}, 46.45$ (46.38); H, 5.12 (4.53); N, 11.51 (11.53)\%. ESI-MS (MeCN, pos. mode) calcd (found) $\mathrm{m} / z=434.61$ (434.61, $\left[\mathrm{Co}_{2}(\mathrm{bpbp})\left(\mathrm{NH}_{2} \mathrm{bdc}\right)+\mathrm{H}^{+}\right]^{2+}$, $\left.\mathrm{C}_{44} \mathrm{H}_{45} \mathrm{Co}_{2} \mathrm{~N}_{7} \mathrm{O}_{5}, 96 \%\right), 868.21$ (868.20, $\left[\mathrm{Co}_{2}(\mathrm{bpbp})\left(\mathrm{NH}_{2} \mathrm{bdc}\right)\right]^{+}$, $\mathrm{C}_{44} \mathrm{H}_{44} \mathrm{Co}_{2} \mathrm{~N}_{7} \mathrm{O}_{5}, 100 \%$ ), 931.20 (931.20, $\left[\mathrm{Co}_{2}(\mathrm{bpbp})\left(\mathrm{NH}_{2} \mathrm{bdc}\right)+\right.$ $\left.\mathrm{NO}_{3}{ }^{-}\right]^{+}, \mathrm{C}_{44} \mathrm{H}_{45} \mathrm{Co}_{2} \mathrm{~N}_{8} \mathrm{O}_{8}, 29 \%$ ). IR (FT-ATR diamond anvil) $\nu /$ $\mathrm{cm}^{-1}=1604(\mathrm{~m}), 1545$ (m), 1484 (m), 1435 (m), 1331 (s), 1218 (m), 1143 (w), 1041 (w), 967 (w), 883 (w), 829 (m), 766 (s), $720(\mathrm{w})$.

$\left[\left\{\mathrm{Co}_{2}(\mathrm{bpbp})\left(\mathrm{O}_{2}\right)\right\}_{2}\left(\mathrm{Cl}_{2} \mathrm{bdc}\right)\right]\left(\mathrm{NO}_{3}\right)_{4} \cdot \mathbf{1 2 H}_{2} \mathrm{O}\left(\mathbf{2 c}\left(\mathrm{NO}_{3}\right)_{4} \cdot \mathbf{1 2 H}_{2} \mathrm{O}\right)$. 2,5-Dichloroterephtalic acid $(112.8 \mathrm{mg}, 0.48 \mathrm{mmol})$ was added to a solution of $\mathrm{NaOH}$ (38.4 mg, $0.96 \mathrm{mmol}, 2$ eq.) in $\mathrm{H}_{2} \mathrm{O}$ (10 $\mathrm{mL}$ ) and the mixture was gently heated until a clear solution formed whereupon it was added dropwise to a mixture of $\mathrm{Co}\left(\mathrm{NO}_{3}\right)_{2} \cdot 6 \mathrm{H}_{2} \mathrm{O}(558.8 \mathrm{mg}, 1.92 \mathrm{mmol})$ and bpbp $(549.4 \mathrm{mg}$, $0.96 \mathrm{mmol})$ in acetone-MeOH $(3: 1,100 \mathrm{~mL})$. Slow evaporation of the resulting dark brown solution yielded black needle-like crystals which were collected by filtration, washed with ice cold $\mathrm{H}_{2} \mathrm{O}(3 \times 5 \mathrm{~mL})$ and air-dried $(575.2 \mathrm{mg}, 0.30 \mathrm{mmol}, 62.0 \%)$. Anal. calcd (found) for $\mathrm{C}_{80} \mathrm{H}_{104} \mathrm{Cl}_{2} \mathrm{Co}_{4} \mathrm{~N}_{16} \mathrm{O}_{34}\left(2140.41 \mathrm{~g} \mathrm{~mol}^{-1}\right)$ : C, 44.89 (44.89); H, 4.90 (4.36); N, 10.47 (10.43)\%. ESI-MS (MeCN, pos. mode) calcd (found) $m / z=461.07$ (461.06, $\left.\left[\mathrm{Co}_{2}(\mathrm{bpbp})\left(\mathrm{Cl}_{2} \mathrm{bdc}\right)+\mathrm{H}^{+}\right]^{2+}, \mathrm{C}_{44} \mathrm{H}_{42} \mathrm{Cl}_{2} \mathrm{Co}_{2} \mathrm{~N}_{6} \mathrm{O}_{5}, 50 \%\right), 472.05$ (472.05, $\left[\mathrm{Co}_{2}(\mathrm{bpbp})\left(\mathrm{Cl}_{2} \text { bdc }\right)+\mathrm{Na}^{+}\right]^{2+}, \mathrm{C}_{44} \mathrm{H}_{41} \mathrm{Cl}_{2} \mathrm{Co}_{2} \mathrm{~N}_{7} \mathrm{NaO}_{5}$, 17\%), 921.13 (921.11, $\left[\left\{\mathrm{Co}_{2}(\mathrm{bpbp})\right\}_{2}\left(\mathrm{Cl}_{2} \mathrm{bdc}\right)+2 \mathrm{Na}^{+}+3 \mathrm{NO}_{3}{ }^{-}\right]^{2+}$, $\left.\mathrm{C}_{80} \mathrm{H}_{80} \mathrm{Cl}_{2} \mathrm{Co}_{4} \mathrm{Na}_{2} \mathrm{~N}_{15} \mathrm{O}_{15}, 15 \%\right), 922.13$ (922.11, [Co ${ }_{2}(\mathrm{bpbp})-$ $\left(\mathrm{Cl}_{2}\right.$ bdc $\left.\left.)+\mathrm{H}^{+}\right]^{1+}, \mathrm{C}_{44} \mathrm{H}_{42} \mathrm{Cl}_{2} \mathrm{Co}_{2} \mathrm{~N}_{6} \mathrm{O}_{5}, 30 \%\right), 984.11$ (984.11, $\left.\left[\mathrm{Co}_{2}(\mathrm{bpbp})\left(\mathrm{Cl}_{2} \mathrm{bdc}\right)+\mathrm{H}^{+}+\mathrm{NO}_{3}{ }^{-}\right]^{1+}, \mathrm{C}_{44} \mathrm{H}_{42} \mathrm{Cl}_{2} \mathrm{Co}_{2} \mathrm{~N}_{7} \mathrm{O}_{8}, 11 \%\right) . \mathrm{IR}$ (FT-ATR diamond anvil) $\nu / \mathrm{cm}^{-1}=1611(\mathrm{~m}), 1566(\mathrm{~m}), 1480(\mathrm{~m})$, 1331 (s), 1215 (m), 1152 (w), 1084 (w), 1044 (w), 912 (w), 831 (m), $770(\mathrm{~s}), 720(\mathrm{~m})$.

$\left[\left\{\mathrm{Co}_{2}(\mathrm{bpbp})\left(\mathrm{O}_{2}\right)\right\}_{2}\left(\mathrm{~F}_{4} \mathrm{bdc}\right)\right]\left(\mathrm{NO}_{3}\right)_{4} \cdot \mathbf{1 8 H}_{2} \mathrm{O} \quad\left(2 \mathrm{~d}\left(\mathrm{NO}_{3}\right)_{\mathbf{4}} \cdot \mathbf{1 8 H}_{2} \mathrm{O}\right)$. Tetrafluoroterephtalic acid (114.3 $\mathrm{mg}, 0.48 \mathrm{mmol})$ was added to a solution of $\mathrm{NaOH}\left(38.4 \mathrm{mg}, 0.96 \mathrm{mmol}, 2\right.$ eq.) in $\mathrm{H}_{2} \mathrm{O}(15 \mathrm{~mL})$ and the mixture was gently heated until a clear solution formed whereupon it was added dropwise to a mixture of $\mathrm{Co}\left(\mathrm{NO}_{3}\right)_{2} \cdot 6 \mathrm{H}_{2} \mathrm{O}(558.8 \mathrm{mg}, 1.92 \mathrm{mmol})$ and bpbp $(549.8 \mathrm{mg}$, $0.96 \mathrm{mmol})$ in acetone- $\mathrm{H}_{2} \mathrm{O}(1: 1,50 \mathrm{~mL})$ whereupon a precipitate formed. Acetone was added until a clear solution formed (approximately $50 \mathrm{~mL}$ ) and the reaction mixture was stirred at room temperature for approximately 7 days whereupon it had turned into a slightly gelatinous appearance. Filtration through celite yielded a clear dark brown solution which upon slow evaporation gave black needle-like crystals which were collected by filtration, washed with $\mathrm{H}_{2} \mathrm{O}(3 \times 5 \mathrm{~mL})$ and air-dried (622.3 $\mathrm{mg}, 0.32 \mathrm{mmol}, 67.3 \%)$. Anal. calcd (found) for $\mathrm{C}_{80} \mathrm{H}_{114} \mathrm{Co}_{4} \mathrm{~F}_{4} \mathrm{~N}_{16} \mathrm{O}_{40}\left(2251.57 \mathrm{~g} \mathrm{~mol}^{-1}\right)$ : $\mathrm{C}, 42.67$ (42.82); $\mathrm{H}$, 5.10 (4.49); N, 9.95 (9.95)\%. ESI-MS (MeCN, pos. mode) calcd (found) $m / z=463.09$ (463.08, $\left[\mathrm{Co}_{2}(\mathrm{bpbp})\left(\mathrm{F}_{4} \mathrm{bdc}\right)+\mathrm{H}^{+}\right]^{2+}$, $\mathrm{C}_{44} \mathrm{H}_{40} \mathrm{Co}_{2} \mathrm{~F}_{4} \mathrm{~N}_{6} \mathrm{O}_{5}, 80 \%$ ), 925.16 (925.16, [Co 2 (bpbp) $\left.\left(\mathrm{F}_{4} \mathrm{bdc}\right)\right]^{+}$, $\mathrm{C}_{44} \mathrm{H}_{39} \mathrm{Co}_{2} \mathrm{~F}_{4} \mathrm{~N}_{6} \mathrm{O}_{5}, 94 \%$ ). IR (FT-ATR diamond anvil) $\nu / \mathrm{cm}^{-1}=$ 1587 (m), 1480 (m), 1437 (m), 1330 (s), 1213 (m), 1160 (m), 1091 (w), 1057 (w), $996(\mathrm{~m}), 907$ (w), 828 (m), $749(\mathrm{~s})$.

\section{Acknowledgements}

This work was supported by the Danish Council for Independent Research|Natural Sciences. LJC would like to thank Dr Elizabeth Carter for help with VT IR and VT Raman measurements. JS would like to thank Dr Jason Price and Prof. Mikael Håkansson for help with an initial X-ray structural data collections.

\section{Notes and references}

1 T. R. Gaffney, Curr. Opin. Solid State Mater. Sci., 1996, 1, 6975.

2 (a) S. Sircar, M. B. Rao and T. C. Golden, in Adsorption and Its Applications in Industry and Environmental Protection, Vol I: Applications in Industry, Elsevier Science Publ B V, Amsterdam, 1999, vol. 120, pp. 395-425; (b) M. W. Ackley, S. U. Rege and H. Saxena, Microporous Mesoporous Mater., 2003, 61, 25; (c) M. Moliner, C. Mártinez and A. Corma, Chem. Mater., 2014, 26, 246-258.

3 (a) M. Suzuki, T. Ishiguro, M. Kozuka and K. Nakamoto, Inorg. Chem., 1981, 20, 1993-1996; (b) G. Q. Li and R. Govind, Ind. Eng. Chem. Res., 1994, 33, 755-783.

4 (a) L. Vaska, Science, 1963, 140, 809-810; (b) H. Lebel, C. Ladjel, F. Bélanger-Gariépy and F. Schaper, J. Organomet. Chem., 2008, 693, 2645-2648.

5 (a) L. Vaska, Acc. Chem. Res., 1976, 9, 175-183; (b) E. C. Niederhoffer, J. H. Timmons and A. E. Martell, Chem. Rev., 1984, 84, 137-203.

6 (a) H. Nishide, T. Suzuki, R. Nakagawa and E. Tsuchida, J. Am. Chem. Soc., 1994, 116, 4503-4504; (b) N. Preethi, H. Shinohara and H. Nishide, React. Funct. Polym., 2006, 66, 851-855; (c) M. Shoji, K. Oyaizu and H. Nishide, Polymer, 2008, 49, 5659-5664.

7 (a) A. C. Sharma and A. S. Borovik, J. Am. Chem. Soc., 2000, 12, 8946-8955; (b) L. L. Welbes and A. S. Borovik, Acc. Chem. Res., 2005, 38, 765-774; (c) R. J. P. Corriu, E. Lancelle-Beltran, A. Mehdi, C. Reyé, S. Brandés and R. Guilard, J. Mater. Chem., 2002, 12, 1355-1362.

8 P. D. Southon, D. J. Price, P. K. Nielsen, C. J. McKenzie and C. J. Kepert, J. Am. Chem. Soc., 2011, 133, 10885-10891.

9 L. J. Murray, M. Dinca, J. Yano, S. Chavan, S. Bordiga, C. M. Brown and J. R. Long, J. Am. Chem. Soc., 2010, 132, 7856-7857.

10 E. D. Bloch, L. J. Murray, W. L. Queen, S. Chavan, S. N. Maximoff, J. P. Bigi, R. Krishna, V. K. Peterson, F. Grandjean, G. J. Long, B. Smit, S. Bordiga, C. M. Brown and J. R. Long, J. Am. Chem. Soc., 2011, 133, 14814-14822. 
11 M. S. Vad, F. B. Johansson, R. Kirk Seidler-Egdal, J. E. McGrady, S. M. Novikov, S. I. Bozhevolnyi, A. D. Bond and C. J. McKenzie, Dalton Trans., 2013, 42, 9921-9929.

12 H. Wackerbarth, F. B. Larsen, A. Glaargaard Hansen, C. J. McKenzie and J. Ulstrup, Dalton Trans., 2006, 34383444.

13 M. Ghiladi, J. T. Gomez, A. Hazell, P. Kofod, J. Lumtscher and C. J. McKenzie, J. Chem. Soc., Dalton Trans., 2003, 1320-1325.

14 F. B. Johansson, A. D. Bond and C. J. McKenzie, Inorg. Chem., 2007, 46, 2224-2236.

15 (a) C. F. Macrae, P. R. Edgington, P. McCabe, E. Pidcock, G. P. Shields, R. Taylor, M. Towler and J. van de Streek, J. Appl. Crystallogr., 2006, 39, 453-457; (b) C. F. Macrae, I. J. Bruno, J. A. Chisholm, P. R. Edgington, P. McCabe, E. Pidcock, L. Rodriguez-Monge, R. Taylor, J. van de Streek and P. A. Wood, J. Appl. Crystallogr., 2008, 41, 466-470.

16 F. H. Allen, Acta Crystallogr., Sect. B: Struct. Sci., 2002, 58, 380-388.

17 D. W. Breck, in Zeolite Molecular Sieves: Structure, Chemistry and Use, John Wiley \& Sons, Inc., New York, NY, USA, 1974, pp. 593-724.

18 (a) J. Tian, P. Thallapally, J. Liu, G. J. Exarhos and J. L. Atwood, Chem. Commun., 2010, 47, 701-703; (b) W. Yang, A. J. Davies, X. Lin, M. Suyetin, R. Matsuda,
A. J. Blake, C. Wilson, W. Lewis, J. E. Parker, C. C. Tang, M. W. George, P. Hubberstey, S. Kitagawa, H. Sakamoto, E. Bichoutskaia, N. R. Champness, S. Yang and M. Schröder, Chem. Sci., 2012, 3, 2933-2999.

19 (a) T. Jacobs, G. O. Lloyd, J.-A. Gertenbach, K. K. MüllerNedebock, C. Esterhuysen and L. J. Barbour, Angew. Chem., 2012, 124, 4997-5000; (b) T. Jacobs and L. J. Barbour, CrystEngComm, 2012, 15, 1512-1514; (c) L. Dobrzańska, G. O. Lloyd, C. Esterhuysen and L. J. Barbour, Angew. Chem., Int. Ed., 2006, 45, 5856-5859.

20 (a) O. V. Zenkina, E. C. Keska, R. Wang and C. M. Crudden, Angew. Chem., Int. Ed., 2011, 50, 8100-8104; (b) C. G. Bezzu1, M. Helliwell, J. E. Warren, D. R. Allan and N. B. McKeown1, Science, 2010, 327, 1627-1630; (c) M. Albrecht, M. Lutz, A. L. Spek and G. van Koten, Nature, 2000, 406, 970-974; (d) Z. Huang, P. S. White and M. Brookhart, Nature, 2010, 465, 598-601; (e) M. A. Garcia-Garibay, Angew. Chem., Int. Ed., 2007, 46, 8945-8947.

21 M. R. Rosenthal, J. Chem. Educ., 1973, 50, 331.

$22 S A D A B S$, Bruker AXS Inc., Madison, Wisconsin, USA, 2001. 23 G. M. Sheldrick, Acta Crystallogr., Sect. A: Cryst. Phys., Diffr., Theor. Gen. Crystallogr., 2008, 64, 112-122.

24 M. Ghiladi, C. J. McKenzie, A. Meier, A. K. Powell, J. Ulstrup and S. Wocadlo, J. Chem. Soc., Dalton Trans., 1997, 21, 40114018. 